\title{
Turkey's CounterRevolution: Notes From the DARK Side
}

\author{
Jeremy Salt
}

\author{
Dr. Salt is an associate professor of political science at Bilkent University \\ in Ankara.
}

I n 1908, the Ottoman Third Army marched from Macedonia to Istanbul and forced the sultan to restore the constitution, introduced in 1876 and suspended in 1878 under the duress of war with Russia. In 1909, chanting crowds of religious students (softas) and turbaned clerics, along with disaffected soldiers, swarmed through the streets of Istanbul, demanding an end to constitutional government and the introduction of sharia law. Revolution had been followed by a counterrevolution, but the army struck back and sent the sultan into exile. Dervis Vahdeti, head of the Muhammadan Society and publisher of the newspaper Volkan (Volcano), was hanged - along with many others - for his central role in instigating the uprising. In 1923, the revolution was consolidated with the establishment of the Turkish Republic. It took shape according to the vision of its founder, Mustafa Kemal "Ataturk," and thus was modernizing and secular, confining religion to the mosque and the home, and emancipating women. The state was also one-party and authoritarian, driving political Islam and Kurdish identity underground, only for them to rise to the surface again decades later.

"Democracy" came to Turkey in 1946, but the military remained the guardian of the state and what it regarded as "Kemalist values." It struck down civilian governments in 1960 and 1980 and drove the Islamist Refah (Welfare) Party out of office in 1997. Political Islam resurfaced in the form of the Justice and Development (Adalet ve Kalkinma) Party (the AKP), elected to office in 2002 with 34 percent of the vote. The AKP government brought down inflation and stabilized the currency, economic and fiscal achievements which, even if they were the legacy of the previous government's policies, helped to account for the 46.6 percent of the vote the AKP received in the 2007 general elections. In March 2008, the public prosecutor asked the Constitutional Court to close the party down after the government lifted the ban on wearing the hijab (head scarf) at state universities. In July, 10 of the 11 judges on the court ruled that the party was a "centre of anti-secular activities," but only six one short of the number needed - voted to close it down. ${ }^{1}$ In June 2011, the AKP won 49.83 percent of the vote in general elections, establishing Prime Minister Recep Tayyip Erdogan, one of the party's founders and a former member of Refah, as the most successful politician in Turkey's history and setting the government up for another electoral victory in 2015.

Middle East Policy (C) 2015, Middle East Policy Counci 
In the fallout from the suppression of the Refah Party, Erdogan, mayor of Istanbul at the time, was jailed for reciting a poem regarded as subversive of the secular order (even though it was written by a founding figure of modern Turkish nationalism, Ziya Gokalp). Learning from his own mistakes and those of his Islamist mentors, he moved cautiously once in government. His most dangerous enemy was the military. At a time when "civilianization" of the military was an issue supported domestically and by the EU, his government initiated the prosecutions of hundreds of senior officers, retired and serving, alleging that they were involved in a conspiracy to overthrow his government. In a country where the military had seemed practically above human intervention, the neutralization of the military through these trials was probably Erdogan's most astonishing achievement.

It was said at the beginning that he had a "secret agenda," and in the 12 years since his party was first elected into government, his plans have slowly unfolded above ground. He once said, "Thank God almighty I am a servant of sharia," "2 and early in the life of his government, he wanted to introduce a specifically Islamic law (zina) criminalizing adultery. He stepped back only in the face of domestic and EU opposition. ${ }^{3}$ Deep structural changes in recent years include educational "reforms" and limitations on a woman's right to choose — not just whether to have a child but how it should be born. The government has employed the machinery of the state to crush dissent on the streets and has intervened in the media - including the Internet and social media - to silence its critics. Purges of police and prosecutors and the tightening of control over the judiciary have eliminated any possibility of an independent inquiry into prima facie evidence of large-scale corruption reaching into the government and circles close to it. The changes that have transformed Turkey since 2002 amount to an incremental counterrevolution largely based on Erdogan's understanding of Islam, seeping slowly into every crevice of state and society and reshaping the structure of both.

\section{THE "NEW" TURKEY}

Erdogan is aggressive and authoritarian; increasingly, he is the state. When he speaks, others follow without question. "Enemies" are being flushed out of the system; the judiciary has been brought under tight government control; intelligence and police powers have been extended; and the media is being harassed. Yet, for his loyal supporters, the leader can do no wrong, no matter how serious the evidence of malfeasance within the government and disruption of the constitutional system. Having held the office of prime minister since 2002, Erdogan was voted into the presidency by more than 52 percent of voters on August 10, 2014. In late October, he moved into a grandiose new presidential palace, built inside the Ataturk Orman Ciftligi (Forest Farm), the first president's personal property, donated to the nation shortly before his death in 1938. Watching the assault on Gezi Park last year, the world did not notice the masses of trees being cut down in Ankara to make way for the residence of a man whose values and vision are the antithesis of Ataturk's. When an administrative tribunal ordered a halt to construction after finding that no proper environmental, historical, cultural or aesthetic concerns had been addressed prior to the removal of the first-degree protected status of the site, Erdogan insisted that the construction 
was not illegal, adding, "If they have the power, let them destroy it."4

Ataturk's Turkey is being disappeared, and as much as Erdogan's supporters adore him, he is loathed by Turks who remain loyal to the founder's vision. Last year, an elderly man walking around the streets of Ankara captured their feelings: stopping every now and then, he quickly drew a side profile of Ataturk on a bank or shop wall before walking away, sometimes with people clapping or coming over to kiss his hands. The country is polarized as never before, with Erdogan frequently sharpening the divisions between "white" (urban middle class) and "black" (urban and provincial poor), between Turks and their foreign enemies, and between Turks and enemies inside their house, especially the "parallel state" (supporters of the Muslim cleric Fethullah Gulen, allegedly inside the government and the bureaucracy).

The symbols of Erdogan's "new Turkey" are everywhere on the landscape. The Gezi Park protests last year were not just about the cutting down of trees but the planned clearing of Taksim Square, symbol of republican Turkey in the 1930s. The plan was to make way for a mosque and a shopping mall inside the reconstruction of a rococo late nineteenth-century Ottoman military barracks that had stood on the site until pulled down in 1940. The project would have involved the demolition of the Ataturk Centre, Istanbul's landmark concert hall, had not the Gezi protests forced the government to shelve it. Erdogan insists that the reconstruction of the barracks (to be turned into a shopping mall around what would have been the parade ground) will still go ahead.

On the Asian side of the Bosporus, another landmark project, a mosque, is being built on top of a hill at Camlica, at 288 meters the highest point in the city. With six minarets, a 70-meter dome and space inside for 37,000 worshippers, the mosque will be tall enough and large enough to compel attention from across the city. ${ }^{5}$ Erdogan has referred to it as a "selatin" (plural of sultan) mosque, such a those the sultans built from their private wealth. This is not the case with the Camlica mosque; the state is paying. Mosques are being built across the country, sometimes so close together that there cannot possibly be a congregation for them. It is what they represent that seems to be the point, not the numbers inside.

There is symbolism also in Erdogan's choice of a site for the new presidential palace. "Historical score-settling" found an opening in the clearing of 22.5 acres in the first president's forest farm to make way for a grandiose 1,150-room presidential palace, Ak Saray (the White Palace), a play on the acronym for the ruling AK Party. ${ }^{6}$ Covering an area of 300,000 square meters, Ak Saray is larger than the palace of the sultan of Brunei. ${ }^{7}$ Erdogan refers to the forest farm area, known until now as Ataturk Orman Ciftligi, as Bestepe. In Istanbul, his official residence is the man- 
Middle East Policy, Vol. XXII, No. 1, Spring 2015

sion of the last Ottoman sultan, Vahdettin, its distinctive onion dome pulled down and reconstructed in concrete to meet the new president's needs.

The substance behind the symbolism is apparent in the reconstruction of the education system, the streaming of students into imam-hatip (prayer leader and preacher) religious schools, and the decree allowing middle and high school girls to wear the hijab in class. ${ }^{8}$ Creationism is reemphasized in textbooks, ${ }^{9}$ and religious instruction focuses overwhelmingly on Sunni Islam, in a country with a large Shia-based Alevi population. In 2012, the school system was completely overhauled. As originally introduced, the " $4+4+4$ " system - four years of first-level primary, four years of secondary-level primary and four years of high school - would have allowed parents to take children out of the school system at the age of 12 to give them distance education or home schooling. For girls, this was likely to lead to unpaid domestic labor and early marriage, especially in regions where polygamy through an informal mosque ceremony is quite common. Popular protest forced the government to drop this aspect of the legislation, but the law still allows children to be transferred to vocational high schools to learn such skills as car care and hairdressing. Only time will tell of the effect this has had on their lives, especially on the lives of young girls whose conservative religious parents do not place the same emphasis on education for girls as for boys. Channeling young people into a religious education has been furthered by allowing imam-hatip schools to take in students from the age of 10 , instead of 15 , as before. Furthermore, the number of these schools has been rapidly increased through the transformation of regular high schools into imam-hatip schools. In some cases, primary-school students have been channeled into these schools, for zoning reasons, whether they and their parents like it or not. ${ }^{10}$

While imam-hatip schools are religion-based, religion and ethics classes are compulsory in all schools. Christian and Jewish students are exempt, but Alevis are not and have complained in an action filed with the European Court of Human Rights (ECHR) that their children were being subjected to a Sunni understanding of Islam that treated "the Alevi faith as a tradition or culture and not as a belief system in its own right." 11 The court ruled that, in forcing students to attend religion and ethics classes, the Turkish government was violating their rights. Critics say that these classes are a form of Sunni indoctrination. Erdogan's occasional slighting references to Alevis and the refusal of the parliament to allow space for a cem evi (Alevi house of prayer) within its grounds have reinforced Alevi dislike of his government and suspicion of its motives.

A further avenue of religious influence on education is the Diyanet (Directorate of Religious Affairs), which receives more government funding than the total sum allocated to nine ministries. ${ }^{12}$ The Diyanet has just inaugurated Turkey's first "religious complex" in the western city of Bursa. This compound will include the Diyanet Academy, with an imam-hatip high school, a mosque, student dormitories and a kindergarten. The Diyanet is also planning to open an "international Islamic university" as an alternative to Al-Azhar in Cairo and Islamic universities elsewhere; the site would be the current May 29 University on the Asian side of the Bosporus. Through the Religious Affairs Foundation, the Diyanet sponsors scholarships for thousands of students from Muslim countries. 
It appoints mosque functionaries, decides the contents of the Friday sermons, is a major publisher of religious books and has a pervasive influence across the culture.

\section{DECIDING FOR WOMEN}

Education, indoctrination, social pressure and fertility are the means by which Erdogan's "pious generations" will be created. On one day he says every woman should have three children, and on another that they should have five, exhorting women to play their part in the creation of the "new Turkey," irrespective of acute economic pressures. Erdogan once remarked, "I don't believe in equality between men and women,"13 a position backed by the actions of his government and statements of ministers, advisers and bureaucrats. He has since clarified his position by stating that women are not equal to men but rather "equivalent" to them. His prime minister, Ahmet Davutoğlu, has linked high suicide rates in developed countries (specifying Scandinavia) to "mechanical equality" in gender relations.

The Law for the Protection of the Family and Prevention of Violence against Women puts the onus on women to prove the violence and calls on them to seek reconciliation rather than resolution through the legal system. In recent years, Turkey has experienced a surge in the murder of women, mostly "honor" killings at the hands of husbands or former husbands, which rose from 66 in 2002 to 847 in the first nine months of 2013. ${ }^{14}$ Erdogan has explained away the increase by claiming that more murders of women are being reported, not that more are being committed. Like Christian fundamentalists everywhere, he has likened abortion to murder. Referring to the killing of 34 Kurds by the air force at Uludere in 2011, attacked in the belief that they were PKK militants, he remarked that "every abortion is a Uludere."

He also regards abortion and even caesarean births - because of the belief that they reduce a woman's ability to have more children — as a "secret plot" against Turkey's population and economic growth ${ }^{15}$ and has referred to contraception as "treason," accusing his political opponents of "betraying" the country by promoting birth control and trying to "dry up" coming generations. In July 2012, the government passed legislation allowing caesarean births only in the case of medical emergency and fining doctors who persuade women to have them "unnecessarily." 16 Who decides what is necessary is not made clear. Turkey has one of the highest caesarean birth rates in the world, and the debate includes claims of profit-seeking by private hospitals, the reality of natural difficulties in labor and the fact that women are having children at a later age, when "natural" birth can be difficult. For many women, the central point is that the government is taking choice out of their hands.

Abortion is still legal up to 10 weeks, but it is subject to such conditions as to be virtually unobtainable in state hospitals. There have been reports of women being given abortions without anaesthesia and of the Ministry of Health requiring laboratories to provide details of pregnancy tests, including the names and mobile phone numbers of women who test positive. ${ }^{17}$ Dr. Cansun Demir, the head of the Turkish Society of Obstetricians and Gynaecologists, believes the government decided "behind closed doors" not to fund abortions. Without funds, the hospitals cannot provide them. "What is left to doctors is either classifying any abortion as a medical necessity or redirecting the woman to seek 
private care to terminate the pregnancy."18 In the opinion of a former health minister, Mehmet Muezzinoglu, "Is abortion a disease? No. Why should the government pay for it?"19 Another former health minister, Recep Akdag, has said that rape victims should give birth and the state "can look after the babies" if necessary. ${ }^{20}$ Other suggestions include the woman's marrying her rapist. AKP member Ayhan Sefer Ustun, speaking as chairperson of the parliamentary Commission of Human Rights, said that abortion is worse than rape. ${ }^{21}$

The human tragedies behind these attitudes surface in accounts of a woman who killed herself because she was denied abortion in a state hospital and a 15-year-old rape victim who was also prevented from terminating her pregnancy. The mayor of Ankara, Melih Gokcek, said the fetus was not to blame for the pregnancy and that mothers seeking abortion should kill themselves instead - taking the fetus with them, of course..$^{22}$ Restrictions on the right of women to choose have now extended to this admonition by Deputy Prime Minister Bulent Arinc in a speech on moral corruption: women should not laugh in public. The statement had women laughing in public more loudly than ever.

\section{ERGENEKON AND GULEN}

In mythology, Ergenekon ("happy valley") was the place where Turks rested when riding westward out of central Asia. More recently, it is the name given to an underground network or "parallel state" allegedly involved in plotting against the government. This is not the first time the phrase has been used. The original "parallel state" or "deep state" (derin devlet) or "Mafia state," as some have called it, is believed to have been an arm of the Gladio underground network established in West- ern Europe after 1945 in case the Cold War turned hot. Over time, the Turkish branch metastasized into a general antileft movement believed to be responsible for provocations such as the shooting into crowds of demonstrators in Taksim Square on May Day 1977. Thirty-four people were killed in the melee that followed. Military intervention in 1980 was followed by a purge of leftist activists, academics and bureaucrats. In the 1990s, the parallel state targeted Kurdish journalists in the southeast as well as journalists and academics in western Turkey. Bahriye Ucok, a professor in Ankara University's Faculty of Theology, was murdered with a parcel bomb; the journalist Ugur Mumcu with a car bomb. Many others fell to an assassin's bullet or bomb or simply disappeared. When the AKP government began its crackdown on the parallel state, it was assumed by many that the perpetrators of these crimes in the 1980s and 1990s might finally face justice. Instead, the government focused on conspiracies it claimed had been hatched within the military since it came to power. Most of the crimes of the ' $80 \mathrm{~s}$ and '90s have never been solved.

The central Balyoz (Sledgehammer) military plot in the Ergenekon trials was said to involve assassination and plans to bomb mosques. Ultimately more than 300 senior and retired officers - up to the rank of commanders in the army, air force and navy — were prosecuted and imprisoned. At least some of the evidence seems to have been falsified: an appointment made on a ship in 2003 when the ship was not built until 2005; street names that were different in 2003; a document said to have been typed in Calibri in 2003, before the font was introduced; a document said to have been written on a day when the purported writer was sea diving. ${ }^{23}$ The release 
of most of the officers in June 2014 seems to have been a byproduct of the breakup of the tacit Gulenist-Erdogan alliance. The formal reason

for their release was that their rights had been violated. With Erdogan now on the warThere was never any joint program as such, but in their different ways Erdogan and Gulen have been working towards the same goal, the re-Islamisation of Turkish society. suggested that Gulenists inside the judiciary had manipulated the evidence leading to the prosecutions. Now, thanks to the AKP government, those wrongfully prosecuted and imprisoned were being released.

The Gulenists are followers of Fethullah Gulen, an imam who lives in a gendersegregated compound in Pennsylvania and is the inspiration for an international network of schools and societies based on social peace through "dialogue." Gulenfriendly banks, corporations, newspapers and television stations provide financial and social support. The sweetness and light emanating from Pennsylvania is deceptive, however. Gulen is politically astute and not just the simple Muslim preacher hoca effendi (dear teacher) - beloved of his followers. He has spoken aggressively against Kurdish separatists and against Turks who think Turkey should be part of Europe, calling them freeloaders and parasites. ${ }^{24}$ Though Gulen charter schools in the United States have no option but to be free and open, the schools in Turkey are characterized by close supervision of students, particularly through the mentoring of young men and women by older abis and ablas, big brothers and sisters.

There was never any joint program as such, but in their different ways Erdogan and Gulen have been working towards the

same goal, the re-Islamisation of Turkish society. If critical mass could be achieved, the desecularization of the state through

the democratic choice of an indoctrinated and re-engineered people would be the logical next step. ${ }^{25}$ Both men have spoken cynically of how to use the system to their own advantage. Erdogan reportedly once said that democracy was like a tram: "You ride it until you reach your destination, then you get off." 26 In the 1990s, Gulen was recorded giving this advice to his followers:
You must move in the arteries of the system without anyone noticing your presence until you reach all the power centres .... Until the conditions are ripe they [his followers] must contin- ue like this .... If they do something prematurely the world will crush our heads and Muslims will suffer every- where .... You must wait until such time as you have taken all the state power .... Until that time any step taken would be too early, like break- ing an egg without waiting the full 40 days for it to hatch. ${ }^{27}$

When the speech was leaked in 1999, Gulen fled to the United States to avoid possible prosecution. In 2008, after the Bush administration dropped its objections, he was finally given a green card.

Gulen's sermons are based on the Quran and the writings of Bediuzzaman Said Nursi (1877-1960). This ethnically Kurdish Sunni Muslim theologian, born in the southeastern city of Urfa, advocated the teaching of religion in secular schools 
Middle East Policy, Vol. XXII, No. 1, Spring 2015

and secularism in religious schools. Gulen's disciples are known collectively as the cemaat (community). Gulen rejects the word "movement," asserting that "my role is very limited .... There is no leadership, no centre, no loyalty to a centre and no hierarchy." ${ }^{28} \mathrm{He}$ prefers the word hizmet (service) to describe his (non-) movement's activities. Surface amity between Erdogan and Gulen concealed suspicion and differences of ideological orientation. Erdogan's socioreligious roots lie in the Naqsibandi sufi (tarikat) movement and an imam-hatip-school education: his politicalIslamic roots are founded in the milli görüs (national view) outlook of Necmettin Erbakan and indicate an affinity with the Muslim Brotherhood.

After forming a "tacit coalition" with Gulen in 2002, two years later Erdogan was having the Gulenists watched. ${ }^{29}$ In 2009 , the public exposure of intelligence chief Hakan Fidan's secret talks with the PKK was regarded by the government as the work of Gulenists. ${ }^{30}$ In 2010, Gulen spoke against the Mavi Marmara aid mission to Gaza, but it was not until 2013 that these inner tensions exploded. Swinging an axe at the Gulen network's social roots, the government announced that all university entrance-exam preparatory schools (dershaneler) would be closed. The Gulenists, controlling about 30 percent of these schools, were the main target: the rest were just collateral damage. Erdogan called the Gulenists "leeches" and "Hashashin" (assassins), a reference to the followers of the eleventh century Ismaili figure, Hassan iSabbah, sent from the mountains of Persia to assassinate ministers of the Sunni Muslim Abbasid state based in Baghdad, and even talked of seeking Gulen's extradition. The phrase "parallel state" resurfaced, but this time in the context of the allegedly subversive actions of Gulenists within the bureaucracy.

Erdogan's attacks brought on an extraordinary display of public anger by Gulen after the government began "reassigning" allegedly Gulenist prosecutors and police. Usually restrained and calm, he was filmed waving his arms as he cursed the government, indirectly if not by name: "Those who don't see the thief but go after those trying to catch the thief, who don't see the murder but try to defame others by accusing innocent people - let Allah bring fire to their houses, ruin their homes, break their unities ...." ${ }^{31}$ Behind the sound and fury, a central question remains: What was the real object of this exercise, the purging of Gulenists within the government because they were Gulenists or the suppression of charges of financial corruption against government ministers and members of their families, with talk of the "parallel state" used as a smokescreen?

\section{THE SHOEBOX SCANDAL}

On December 17, 2013, prosecutors filed charges of corruption against high officials and the sons of two government ministers. Police found $\$ 4.5$ million stacked in a shoebox in the house of the general director of the state-owned Halkbank. Millions more dollars or euros were found in the homes of the sons of the two ministers. The corruption charges involve tender rigging, money laundering for Iran and deals with a Saudi businessman, Yasin Al Qadi. Al Qadi has been waging court battles in the United States and Europe to remove sanctions and asset freezes based on accusations that he is a sponsor of terrorism. On his frequent trips to Istanbul, Al Qadi reportedly entered Turkey without a visa and was escorted from the airport by the then prime minister's security 
staff. Another key figure named in the charges was an Iranian, Reza Zarrab, who is married to the Turkish pop diva Ebru Gundes. Erdogan defended both Zarrab and Al Qadi. "I know Yasin," he has said. "I believe in him as I do myself. He is a charitable person who loves Turkey." ${ }^{2}$

By the time a second round of charges was prepared against 41 people, including Erdogan's son Bilal, the government had begun "reassigning" prosecutors and police. The justice minister ordered police not to act on arrest warrants. The widening net threatened to pull in Erdogan as well, initially through allegations that he received two villas on the coast near Izmir in return for the easing of a ban on construction in an environmentally protected area. His claim that the villas had been there for 35 years was belied by a Googlemap search showing they had to have been built after $2010 . .^{33}$ In a leaked conversation with Erdogan, the developer, Mustafa Latif Topbas, complaining of the problems he is having with local authorities, can be heard saying, "you'll give someone the message, inshaallah [God willing.]" ${ }^{34}$ Four months after opposing the construction of the buildings, the governor of Izmir, Cahit Kirac, was transferred to Diyarbakir. His environmental and urban-planning director, who reportedly refused to help Topbas with his application, was subsequently removed from his post. ${ }^{35}$

The truth or falsity of this allegation was soon swamped by the startling revelations coming out of the five wiretapped conversations Erdogan and his son allegedly had on December 17, the day prosecutors brought their first round of corruption charges ${ }^{36}$ Not once actually using the word "money" but rather "it" or the "thing" (sey), Erdogan refers to the 18 people who had been charged and instructs his son to get rid of large amounts of money being held at five different family addresses. Bilal is to meet his uncle Mustafa, older brother Burak and brother-in-law Berat and they are to remove all the money they have in their houses. Erdogan's wife, Emine, can be heard making suggestions in the background. The prime minister mentions another brother-in-law, Ziya, but does not know whether he has any money or not. "Whatever you have in your house you get it out, OK?" he tells Bilal. "What would I have, father?" Bilal replies. "Your money is in the safe." Erdogan responds, "That's what I am talking about." He says he is sending over Bilal's sister, Sumeyye. "Is Sumeyye going to tell me where to take it?" Bilal asks. The amount of money is so great that at one stage Bilal refers to the difficulty of shifting it because "it takes too much space." He believes it might be better to move the money after dark. When he refers to specific amounts, Erdogan cautions him: "Don't speak so openly." There are other references to the need to be careful. In one conversation Erdogan warns Bilal, "Son, you're being listened to."

Bilal tells his father that Sumeyye has "sorted out both sides" and "emptied them both." Bilal is obviously having some difficulty spreading the cash around. One contact "can only take 10 million euros." Some is given to a businessman called Faruk Kalyonculu, who "can work it the same way as he did with the other money." By evening there are still 30 million euros left over, but Bilal thinks most of it can be given to a businessman to whom they owe money; the rest can be used to buy real estate. In the last conversation, beginning at 10:58 p.m., Bilal reports that he has completed his task with the exception of a few hundred thousand dollars and some Turkish lira. The amount of money 
Middle East Policy, Vol. XXII, No. 1, Spring 2015

that needs to be shifted is so great that another recently leaked conversation by the hacker Haramzadeler ("bastard sons"), in which the prime minister tells Bilal to hold out for more than the $\$ 10$ million he has been offered by a businessman, reads almost like a minor footnote. "Don't take it," Erdogan tells his son. "Whatever he has promised, he should bring more. If he is not going to bring that, there is no need .... The others are bringing. Why can't he bring? What do they think this business is? But don't worry, they will fall into our laps." ${ }^{37}$

These allegations sent shock waves across the country. They were dismissed by Erdogan as being a "montage," with the corruption charges represented as the Gulen movement's striking back through its supporters in the police and judiciary. The then prime minister retaliated forcefully. Hundreds of prosecutors and more than 10,000 police were "reassigned" in the coming months, with the purging of suspected Gulenists reaching into other ministries. Prosecutions of those alleged to have been involved in illegal wiretapping followed. Intervention in judicial processes brought strong criticism from the Supreme Council of Judges and Prosecutors before it was brought under the close control of the executive. ${ }^{38}$ Police were given sweeping new powers of arrest, detention and seizure of assets.

Other legislative measures strengthened the remit of the National Intelligence Organization (MIT) and gave the government greater powers to intervene in the Internet and remove content it did not like. Bans on Facebook and Twitter were part of the campaign to suppress the public airing of accusations of corruption: Twitter users accused of insulting government officials faced prosecution, while 35 Gezi Park demonstrators were charged with trying to overthrow the government, the prosecutor demanding "aggravated life sentences." 39 Those charged included members of the Besiktas football-club support group. The performance of some of them in court was droll: they argued that it was not the government they wanted to overthrow but their chief rival on the football field.

The suppression of dissent extended to the universities. A regulation passed by the Higher Education Council (YOK) stipulates that academics at state institutions — therefore, state employees — would be subject to censure for speaking to the media on official matters without the approval of a higher authority. This has now been used against an academic who questioned, on valid grounds, the constitutionality of Erdogan's running for president while still holding public office as prime minister. ${ }^{40}$ Thousands of Turks and foreigners are being watched. ${ }^{41}$ At the same time, all corruption charges brought in late 2013 and early 2014 were eventually dropped and all 53 suspects cleared. In January 2015, a parliamentary commission of inquiry voted against sending four government ministers to the Constitutional Court to face charges of corruption. The vote was split along party lines, with the AKP chairman of the commission calling on the chief prosecutor in Istanbul to destroy the evidence contained in wiretapped phone calls.

\section{MARAUDERS, ATHEISTS AND ROBOTS}

With the AKP's majority in parliament solid, with the judiciary in its hands, and with prosecutors and police "reassigned," the role of the media became more important than ever in standing against what many commentators saw as a continuing assault on the rule of law. Parts of the me- 
dia are taking the fight to the government, but other outlets have been intimidated. Even before the corruption scandal broke, the jailing of journalists and publishers had given Turkey one of the worst reputations in the world for assaults on freedom of the press. The sacking of journalists under pressure from behind the scenes and Erdogan's encouragement of friendly businessmen to raise funds for the purchase of the Sabah/ATV conglomerate — now slavishly pro-government — are all playing out in the media. Influential organs of both print and broadcast have been shying away from telling the people exactly what is involved.

The Gezi protests were poorly covered by the mainstream media; at the height of police brutality, CNN Turk ran a documentary on penguins. ${ }^{42}$ When the CHP (People's Republican Party) leader, Kemal Kilicdaroglu, addressed parliament in February 2014 on the subject of the tapes of the December 17 conversations, CNN Turk, NTV, Haberturk and the parliamentary television station all cut the broadcast. Reporters Without Borders (RSF) has called the Turkish government an "enemy of the Internet," a judgment justified by its banning of thousands of web sites, by Erdogan's personal view that he is " increasingly against the Internet every day" and by the announcement in which the government gave itself the authority to intervene in the Internet without a court order "to protect national security [and] public order and to prevent crime." 43

Erdogan's abuse of his critics since Gezi Park has been nothing if not inclusive. In his view, the protests were the work of looters, banks, Turkish holding companies (one of which, Koc, owns the Divan hotel, in whose lobby tear-gassed demonstrators sought refuge), foreigners, marauders (capulcular) and the "interest- rate" lobby - categories that have now been expanded to include atheists, leftists, terrorists and the Gulenist "assassins." The "terrorists" included a 14-year-old boy, Berkin Elvan, hit on the head by a tear-gas canister after he was sent out to buy a loaf of bread; he died in a coma nine months later. When Erdogan mentioned the boy's mother at a rally, she was jeered by the crowd. ${ }^{44}$ When protestors wanted to commemorate the boy's death, he retorted, "What is this? They wanted to hold a ceremony to commemorate Berkin Elvan. Will we perform a ceremony for every death? He died and it's over."45

Protests against legislation giving the government power to remove material from the Internet were dismissed by Erdogan as being the work of the "porno" lobby. Allegations against him personally came from "Peeping Toms" and the "robot lobby" in the social media. ${ }^{46}$ The television presenter Yigit Bulut even claimed that attempts were being made from afar to murder Erdogan by telekinesis. This "climber of many greasy poles" was subsequently appointed one of Erdogan's senior advisers. ${ }^{47}$ Tension in the country has been reflected by brawling in the parliament. A judge was karate-kicked by a member of the ruling party during a melee in a committee room, with a brawl subsequently breaking out in the Chamber of Deputies itself. One MP had his nose smashed, another's finger was broken, and a third was put in a headlock as he was wrestled to the ground. Disquiet within the ruling party at Erdogan's behavior has led to some resignations by parliamentarians and rank-and-file members, but the hardcore remains solid.

In May 2014, more than 300 miners died, most from carbon monoxide poisoning, when an explosion triggered a fire in 
Middle East Policy, Vol. XXII, No. 1, Spring 2015

a mine near the western Anatolian town of Soma. Erdogan responded to the disaster by remarking that death was an "occupational hazard" of mining, a statement reminiscent of an earlier observation after another mine disaster: "Dying is the fate of the miner."48 Visiting the town, he was hemmed in by demonstrators and ushered into a small supermarket for safety. Angry at the booing, he was caught on camera hitting a man whom his bodyguards then beat up. Showing his bruises on television, the man said Erdogan had called him "Israeli sperm," not an expression he was likely to have made up. ${ }^{49}$ Earlier, a man who had lost family in the disaster had been wrestled to the ground by paramilitary jandarma after kicking the side of an official car. One of Erdogan's senior advisers ran up and kicked him solidly several times; he neither resigned nor was sacked but was allowed to take time off to recover from soft-tissue damage to his leg. ${ }^{50}$ Not even video evidence of the leader and one of his advisers assaulting the citizenry seems have to have dented Erdogan's support base. When Der Spiegel ran an article on Soma quoting the bitter remark of a miner, "Go to hell Erdogan," its Turkish-German reporter was bombarded with 10,000 Twitter, Facebook and email messages threatening to kill him — one specifically by cutting his throat. He had to be withdrawn from the country for his own safety. ${ }^{51}$

\section{THE SYRIA IMBROGLIO}

Turkey's foreign policies have been reshaped along with everything else. Accession to the EU has been pushed so far onto the back burner as to be stone cold (though as much the fault of the EU as Turkey). In 2011, an effective "zero problems with neighbors" approach was dumped in favor of a dominant role inside the collective of governments assembled to bring down Bashar al-Assad in Damascus. The armed groups they have sponsored have produced shattering consequences for Syria and increasingly disastrous ones for Turkey as well. Out of these motley groups has arisen the Islamic State. By October 2014, taking advantage of the chaos created through intervention in Iraq and Syria, it had overrun much of western Iraq as well as swaths of territory in northeastern Syria before its momentum was blocked by the Kurds at Kobane (Ayn al Arab).

The fallout from a backfiring Syria policy included the negative effects on Turkey's relations with Russia, Iran and Iraq. Others have also been offended: Egypt, Saudi Arabia and the UAE, because of Erdogan's outspoken support for the Muslim Brotherhood and, in Egypt's case, continuing criticism of the Sisi government; European governments and the United States because of the brutality of the Gezi Park crackdown and continuing harassment of the media; and Israel because of Erdogan's open hostility going back many years. Even the United States has been looking askance at the statements coming out of the Turkish government. Turkey is too important to be ignored, but has rarely seemed so friendless in the world.

Erdogan's talent for abrasive exchanges first came to global attention during a televised debate with Israeli President Shimon Peres at Davos in 2009. The moderator allowed Peres to speak at length but tried to cut Erdogan off after a few minutes. Erdogan kept speaking, and when the moderator persisted he got up and walked out, vowing never to return and snapping at Peres that "when it comes to killing you know how to kill." The outburst turned 
him into an instant (if temporary) hero across the Middle East, feeding Erdogan's apparent view of himself as a neo-Ottoman Islamic redeemer. In 2010, when Israeli commandos attacked the Gaza-bound Mavi Marmara aid ship, killing nine Turks, he called Israel a terrorist and criminal state.

In 2011, it was Bashar al Assad's turn. The uprisings in Tunis and Cairo and the protests breaking out in Benghazi persuaded Erdogan and Ahmet Davutoglu, his foreign minister at the time but now prime minister, that a new Middle East was taking shape and that they had to position themselves on the "right side of history." ${ }^{52}$ Warning at first that armed outside intervention in Libya or anywhere else in the region would be a disaster, Erdogan ended up giving logistical support to the NATO air war. It ended with the killing of thousands of people and the murder of Muammar Qadhafi outside Sirte seven months later.

The United States and its allies then turned their attention to Syria, and Erdogan and Davutoglu turned Turkey into a pivotal player in the campaign to bring down the government in Damascus. They claimed to have done their best to persuade Assad to introduce reforms before dumping him. In fact, according to Syrian Foreign Minister Walid Muallim, what they wanted was for the Muslim Brotherhood - banned since 1963 and having fomented the Hama uprising of 1982 - to be brought into the political process..$^{53}$ Assad, whom only a few months previously the two men had been calling "brother," was sprayed with abuse: he was a coward; he drank the blood of his own people; he would soon be gone; and his end would be the same as that of Qadhafi or Milosevic. ${ }^{54}$

Positioning Turkey in the front rank of the U.S.-led "Friends of the Syrian People," the government turned the southeast into a mobilization zone for the so-called Free Syrian Army (FSA) and threw its weight behind the exiles calling themselves the Syrian National Council (SNC). However, nothing Erdogan and Davutoglu said proved to be correct, and nothing they supported on the ground in the name of bringing down the government in Damascus has worked. In the meantime, more than 200,000 Syrians have died, millions have fled into surrounding countries (including about 1.5 million into Turkey) or have been displaced within the borders of their own country, and enormous damage has been done to civilian and state infrastructure. Assad is still in power, and the FSA and the exile council have turned out to be irrelevant except as propaganda tools. The "moderate rebels" are widely regarded as a fiction ${ }^{55}$ : in a recent speech, U.S. Vice President Joe Biden came close to admitting as much. ${ }^{56}$ Most of the "refugee" camps are located close to Turkey's border with Syria. Officially the refugees are classified as "guests," a device that deprives them of refugee status under the aegis of the UNCHR. The camps have served as rest and recreation for Syrian "rebels" crossing the border to fight with the armed 
Middle East Policy, Vol. XXII, No. 1, Spring 2015

groups before returning to the relative comfort of tents, blankets, food and heating provided by local and international aid agencies. The Apaydin camp has served as a base for the senior figures in the FSA.

Over the past four years, thousands of foreign takfiris (radical jihadis) from more than 80 countries have traveled to Syria, swelling the epicenter of global jihad. Most have flown to Istanbul before making their way to "safe houses" in the southeast: those coming from the Caucasus are able to cross the Georgian border along the eastern Black Sea coast. By late 2014, the Turkish government was insisting that it was doing its best to stem the flow, while preparing to train "moderates" to join the fighting. Cross-border activity from Turkey has included the attack on the Syrian Armenian town of Kassab in March 2014 by an assortment of jihadists, including Chechens. The flight of the townspeople and the desecration of their churches followed. During the assault, a Syrian jet attacking armed groups around the town was shot down after allegedly crossing into Turkish air space, a claim denied by the pilot, who ejected safely several kilometers inside the Syrian border. ${ }^{57}$ Arms have flowed into Syria through Turkey and across other borders. By early 2013, Jordanian, Saudi and Qatari military cargo planes were reported to have flown more than 160 shipments of weapons, including one large consignment from Croatia, directly to Ankara's Esenboga airport or other airports in Turkey or Jordan. ${ }^{58}$ Other shipments came from Libya, which also supplied large numbers of fighting men following the destruction of the government in Tripoli. ${ }^{59}$

Having called in 2012 for a buffer zone to be created across the Syrian border, the Turkish government returned to this point in the autumn of 2014, referring to the Suleyman Shah tomb just across the border as a specific site that might need protecting. Extraterritorial rights to guard this tomb of the grandfather of the first Ottoman sultan were given to Turkey by the French mandatory government of Syria under a treaty signed in 1921. Among the conversations leaked to the media early in 2014 was one in which the then Turkish foreign minister, a senior foreign ministry official, a senior military officer and the head of MIT discussed launching a falseflag attack on this supposedly sacrosanct site to justify intervention. "I'll make up a cause of war by ordering a missile attack on Turkey," the MIT head can be heard saying. "We can also prepare an attack on Suleyman Shah tomb if necessary." He also referred to 2,000 trucks that had been sent from Turkey into Syria, their contents not specified. ${ }^{60}$

Following the rise of the Islamic State, the United States and other governments began calling on Turkey to seal its borders, as if they themselves were not also responsible for the unleashing of takfiri savagery on Iraq and Syria. The ambivalence of the Turkish response to pressure to join the anti-IS coalition ("of the clueless," according to Sharmine Narwani ${ }^{61}$ ) could be justified after the June 2014 seizure by IS militants of 49 Turkish diplomats and their dependents in Mosul. However, even after they were released four months later (apparently traded for 180 IS takfiris held by rival armed groups), the ambiguity continued. As IS forces closed in on Kobane in October, Saleh Muslim, the leader of the Democratic Union Party (PYD), traveled from Kobane to Ankara to seek military support from the Turkish government. He was told he would have it if he aligned the Syrian Kurds with the so-called Free Syr- 
ian Army. Refusing, he returned to Kobane and the onslaught on the town by the Islamic State. While negotiating through intermediaries with the imprisoned head of the PKK (Kurdistan Workers' Party), Abdullah Ocalan, Erdogan has taken a harsh line against the Syrian Kurds because of the close PKK-PYG relationship and the spectre of an expanded Kurdish state. The past few years have been dominated by talk of a "Kurdish peace" inside Turkey, but Erdogan wants to negotiate from a position of strength, and that means controlling the Kurds on both sides of the Turkish-Syrian border. The stout defence of Kobane by the Kurds, with the backing of U.S. air strikes, has set this strategy at odds.

\section{THE WASP'S NEST}

In taking a front-row position in the attack on Syria, Erdogan has emptied a wasp's nest on his own country. He responded to Gezi Park by blaming others, and this is how he has responded to the crisis in Syria: Assad remains the root of all evil, not the Islamic State, not the other armed gangs that have laid waste to the country, and not the governments backing them with money, weapons and territory for mobilization and training. Despite all the evidence that their Syria policy has run into a dead end, Erdogan and Davutoglu insist they were right and that Syria would not be where it is now if only people had listened to them. They continue to argue that no campaign against the Islamic State can succeed unless the Syrian government is also brought down. In late 2014, Davutoglu revived Turkey's proposal for buffer/ no-fly zones to be established across the border. This is unlikely to go any further. Russia and China can be counted on to block any new attempt to win UN Security Council support for the establishment of such zones, and even the United States is not in favor. In Europe, only a French president whose public support is lower than Nicolas Sarkozy's likes the idea.

The Turkish republic is roiled by existential conflict: between the government and the PKK; between nationalist Turks and nationalist Kurds; between Ataturk's secular republic and Erdogan's increasingly religious one; between Erdogan and the Pennsylvania cleric; between Erdogan and Turks who have demonstrated peacefully in the streets, only to be mistreated by police. The military remains part of the equation. The decimation of its senior ranks and humiliation at the hands of Erdogan created a backlash of resignations and refusals of promotion by their junior officers out of loyalty to their superiors, but army commanders have ruled out another bout of intervention, and most commentators agree on its improbability. Economics will continue to tip the balance one way or another. Erdogan looks after his constituents, but the currency is losing value, inflation is up, growth is down, and predictions are grim. ${ }^{62}$ Religion is a great pacifier, and there are limits to what people will accept in return for the promise of eternal redemption, but Erdogan is a seasoned political campaigner and well placed to lead the AKP to another victory when general elections are held in June.

The government might be "neo-Ottoman" in ambition, but its domestic power is the product of tools made available to it by modernity. Indeed, there is no precedent in Ottoman history for the systematic way in which the AKP government has managed to re-engineer society, with near-majority electoral support. Consensual authoritarianism might best define the relationship. Erdogan's creeping counterrevolution has already destroyed much of 


\section{"old Turkey." Some of it needed destroy-} ing (the stranglehold of the military), but in its interventionist ${ }^{63}$ authoritarianism, the "new Turkey" duplicates the old while replacing a progressive vision of society with one that many Turks regard as regres- sive and reactionary. The ghost of 1909 is hovering somewhere in the Turkish home. Erdogan has earned a place in history, even if only history can decide what that place will be.

\footnotetext{
${ }^{1}$ The court decided instead to deprive the party of 50 percent of its state funding, which, given its corporate support, was unlikely to damage it. See "Turkey's Court Decides Not to Close AKP, Urges Unity and Compromise," Hurriyet, July 29, 2008, www.hurriyet.com.tr/english/home/9547882.asp. See also Sabrine Tavernise, "Turkish Court Calls Ruling Party Constitutional," New York Times, July 31, 2008, www.nytimes. com/2008/07/31/world/Europe/31Turkey.html? r $=0$.

${ }^{2}$ Cuneyt M.Serdar, “Turkey's Disintegrating Democracy,” Los Angeles Times, March 28, 2008, www.latimes. com/opinion/la-oew-serdar-28mar28-story.html.

${ }^{3}$ Zina prohibits all lewd behavior, and not simply sex before or outside marriage. This did not seem to be understood in Turkey. Logically pursued, any zina law could eventually be applied against gay or lesbian relationships.
}

${ }^{4}$ Kadri Gursel, "Erdogan’s $\$ 350$ Million Presidential Palace," AL-Monitor, September 17, 2014. Other estimates put the cost of the palace at $\$ 455$ million. Plans have since been announced to build a 220-room private residence next to Ak Saray, www.al-monitor.com/pulse/originals/2014/09/turkey-erdogan-white-palace-presidential-residence.html.

${ }^{5}$ Nilay Vardar, "Groundbreaking for Camlica Mosque despite Ongoing Trial," English Bianet, August 7, 2013, www.bianet.org/english/environment/149046-groundbreaking-for-camlica-mosque-despite-ongoing/ trial/.

${ }^{6}$ Ibid.

${ }^{7}$ It is "still not that big compared to what Erdogan's ego demands," says the journalist Y1lmaz Ozdil. See "Criticized for Lavishness, Ak Saray May Make It to Guinness Records," Today's Zaman, October 17, 2014, http://www.todayszaman.com/business_criticised-for lavishness-ak-saray-may-make-it-to-guinnessrecords_361924.html.

${ }^{8}$ This was achieved by removing the stipulation that students must be bareheaded. See "Turkey Lifts Headscarf Ban in Schools for Girls as Young as 10," Russia Today, September 23, 2014, www.rt.com/news/90032turkey-headscarf-schools-ban-amendment/. There are various signs that gender-segregated education is moving closer to the top of the agenda.

${ }^{9}$ See Dorian Jones, "Turkey: Creationists Want to Airbrush Darwin out of Evolutionary Picture," Eurasianet, June 7, 2012, www.eurasianet.org/node/65517. Also see Marc Kaufman, "In Turkey Fertile Ground for Creationism," Washington Post, November 8, 2009, www.washingtonpst.com/wp-dyn/content/article/2009/11/07/AR2009110702233.html/. For background, see Umit Sayin and Aykut Kence, "Islamic Scientific Creationism: A New Challenge in Turkey," Reports of the National Centre for Scientific Education 19, no. 6 (November-December, 1999): 18-20, 25-29, www.ncse.com/rncse/19/6/Islamic-scientific-creationism/.

${ }^{10}$ On the educational reforms, see Aysegul Sert, "Turkish Reforms Entangle Education," New York Times, October 12, 2014, www.nytimes.com/2014/10/12/world/europe/turkish-reforms-entangle-education.html?_r=0; Aytug Sasmaz, "4+4+4: Turning the Education System Upside Down," Heinrich Boll Stiftung, tr.boell.org/ de/2014/06/16/444-turning-the-education-system-upside-down/: and Ozlem Ilyas Tulunay, "Women in Erdogan's Turkey," New Politics 15, no. 4 (Winter 2014), www.newpols.org/content/women-erdogans-turkey. ${ }^{11}$ Tulin Daloglu, "European Court Warns Turkey to Respect Parents' Convictions," Al-Monitor, September 18, 2014, http://www.al-monitor.com/pulse/originals/2014/09/turkey-echr-religion-classes-alevi-sunni.html. ${ }^{12}$ Yavuz Baydar, “Diyanet Tops the Budget League," Today's Zaman, October 13, 2013, www.todayszaman. com/diyanet-tops-the-budget-league-329311.html. 
${ }^{13}$ Daniel Steinvorth, 'Erdogan the Misogynist: Turkey's Prime Minister Assaults Women's Rights,” Der Spiegel, June 19, 2012, www.spiegel.de/international/europe/turkish-prime-minister-erdogan-targets-womens-rights-a-839568.html.

${ }^{14}$ Tulunay, op.cit.

${ }^{15}$ Constanze Letsch, "Turkish Women Join Pro-Choice Rally as Fears Grow of Abortion Ban," Guardian, June 3, 2012, www.theguardian.com/world/2012/jun/03/turkish-women-rally-abortionban?guni=Article:in\%20body\%20link. See also Elif Shafak, "This Silence Hurts Women," Guardian, July 15, 2012, www.theguardian.com/commentisfree/2012/jul/15/turkey-caesarean-ban-change-hurts-women. See also a summary by the Turkish opposition Republican People's Party (CHP), "Turkey Abortion Debate: The Council of Europe Criticizes the Proposed Ban on Abortion," June 7, 2012, www.chpbrussels. org/2012/06/07/turkey-abortion-debate-the-council-of-europe-criticises-the-proposed-ban-on-abortion/.

${ }^{16}$ Constanze Letsch, "Turkish Doctors Face Fines for Elective Caesareans," Guardian, July 13, 2012, http://www.theguardian.com/world/2012/jul/13/turkish-doctors-fines-electivecaesarians?newsfeed=true\&guni=Article:in $\% 20$ body\%20link.

${ }^{17}$ Tulunay, op. cit. See also Belgin Tan, "Horror of Abortion without Anaesthetics," Hurriyet Daily News, January 17, 2013, www.hurriyetdailynews.com/horror-of-abortion-without-anaesthetics.aspx.

${ }^{18}$ Pinar Tremblay, “Turkish Laws Fail to Protect Women's Right to Choose," Al-Monitor, March 14, 2014. www.al-monitor.com/pulse/originals/2014/03/turkish-womens-right-to-choose-law-fails-html.

${ }^{19}$ Tulunay, op. cit.

${ }^{20}$ Ibid.

${ }^{21}$ Ibid.

${ }^{22}$ Tremblay, op.cit.

${ }^{23}$ For a useful summary of some of the apparent falsities in the evidence, see Dani Rodrik, "Ergenekon and Sledgehammer: Building or Undermining the Rule of Law?", Turkish Policy Quarterly 10, no. 1 (Spring, 2014). Rodrik, a professor of international political economy at Harvard University, is the son-in-law of General Cetin Dogan, former commander of the First Army and one of the Ergenekon defendants.

${ }^{24}$ Maximilian Popp, "Altruistic Society or Sect? The Shadowy World of the Islamic Gulen Movement," Spiegel Online, August 8, 2012, www.spiegel.de/international/germany/gulen-movement-accused-of-being-asect-a-848763-2.html.

${ }^{25}$ The main barrier would be Article Two of the Constitution, which defines Turkey as a "democratic, secular and social state," and Article Four, which stipulates that Article Two "shall not be amended nor shall the amendment be proposed."

${ }^{26}$ Serdar op. cit. Some references say "bus" but the destination remains the same.

${ }^{27}$ Popp, op. cit.

${ }^{28}$ Brian Knowlton, "Turk Who Leads a Movement Has Advocates and Critics," New York Times, June 11, 2010, www.nytimes.com/2010/06/11/us/iziht-gulen.html?pagewanted=a11\&_r-0.

${ }^{29}$ Pinar Tremblay, "Erdogan's Blacklist," Al-Monitor, December 1, 2013, www.al-monitor.com/pulse/originals/2013/11/turkey-erdogans-blacklist.html.

${ }^{30}$ Daniel Dombey, "Turkish Spy Chief Summoned over PKK Talks," Financial Times, February 9, 2012, www.ft.com/intl/cms/s/o5328-11e1-8aa1-00144feabdc0.html\#cx223FvDxA4el.

31 "For First Time Gulen Curses Purge of Police Officials in Emotional Speech," Today's Zaman, December 21, 2013, www.todayszaman.com/_for-first-time-gulen-curses-purge-of-police-officials-in-emotionalspeech_334604.html.

${ }^{32}$ Richard C. Marais with Denet C. Tezel, "The Al Qadi Affair," Forbes, January 24, 2008, www.forbes. com/2008/01/24/turkey-yasin-al-qadi-biz-cz_rm_0124_alqadi.html.

33 “Erdogan Spends Vacation in Controversial Urla Villas," Today's Zaman, August 21, 2014, www.todayszaman.com/erdogan-spends-vacation-in-controversial-urla-villas_356343.html. A leaked conversation between the developer and Erdogan's daughter Sumeyye centered on what kind of toilets she would like, "oriental" or European.

${ }^{34}$ Reuben Silverman, "Saving the AKP," May 13, 2014. The heading is subtitled AKP or "Ayyakabi Kutusu Partisi (Shoebox Party)," www.reubensilverman.wordpress.com/2014/05/13/saving-the-akp/.

${ }^{35}$ Ibid.

${ }^{36}$ See Jack Moore, “Turkey Youtube Ban: Full Transcript of Leaked Erdogan Corruption Call with Son,” 
Middle East Policy, Vol. XXII, No. 1, Spring 2015

International Business Times, March 27, 2014, www.ibtimes.co.uk/turkey-youtube-ban-transcript-leakederdogan-corruption-case-son-1442150. For audio as well as transcript, "Corruption! Turkish PM Erdogan and His Son's Leaked Conversation,” Live Leak. www.liveleak.com/view?i=f08_1393301418.

${ }^{37}$ Humeyra Pamuk, "Turkish Prime Minister Targeted in Second Audio Tape," Reuters, February 26, 2014, www.reuters.com/article/2014/2/26/us-turkey-erdogan-idUSBREAIPO2K20140226/.

${ }^{38}$ Mustafa Akyol, “Turkish Judiciary Battle:AKP 1, Gulenists 0,” Al-Monitor, October 14, 2014. www.almonitor.com/pulse/originals/2014/10-turkey-judiciary-battle-hsyk-akp-gulen.html.

${ }^{39}$ Ali Aslan Kilic, "New Indictment Accuses Gezi Protestors of Coup Attempt," Today's Zaman, September 8, 2014, www.todayszaman.com/_new-indictment-accuses-gezi-protestors-of-coup-attempt_358046.html. The accused include members of the Beskitas football club support group Carsi (Market).

40 “Aydin University Suspends Law Professor over Complaint against Erdopgan,” Today's Zaman. Professor Hayrettin Okcesir was targeted under a regulation prohibiting academics from speaking out on non-academic matters without higher university authority. Interpretations of the constitution are, of course, an academic matter, www.todasyszaman.com/national_aydin-university-suspends-law-professor-over-complaint-againsterdogan.359377.html.

41 “Turkey Eavesdrops on Almost 2,500 people, Mostly Foreigners," Russia Today, February 23, 2014. www. rt.com/news/turkey-spies-2500-people-300/.

${ }^{42}$ Kerem Oktem, "Why Turkey's Mainstream Media Chose to Show Penguins Rather Than Protests," Guardian, June 9, 2013, http://www.theguardian.com/commentisfree/2013/jun/09/turkey-mainstream-mediapenguins-protests/.

${ }^{43}$ Heather Saul, "Turkish President Tells Conference: I Am Increasingly against the Internet Everyday," Independent, October 3, 2014, http://www.independent.co.uk/news/world/europe/turkish-president-erdogantells-conference-I-am-increasingly-against-the-internet-every-day-9772048.html. See also "Turkey Tightens Internet Censorship with New Law," Al Akhbar English, September 12, 2014, www.english-al-akhbar.com/ node/21499.

${ }^{44}$ Tulin Daloglu, "Erdogan Makes Crowd Boo Berkin Elvan’s Family,” Al-Monitor, March 16, 2014, http:// www.al-monitor.com/pulse/originals/2014/03/erdogan-terrorist-elvan-crowd-incitement-elections.html.

45 “Erdogan on Teen's Death: He's Dead and It’s Over," Today's Zaman, May 23, 2014, http://www.todayszaman.com/news-348629-erdogan-on-teens-death-hes-dad-and-its-over.html.

${ }^{46}$ Burcu Baykurt, "We Are Turkey's Generation Y — Not a Robot Lobby," Guardian, March 19, 2014, http:// www.theguardian.com/commentisfree/2014/mar/19/turkey-generation-y-robot-lobby. Erdogan's wife Emine regards the social media as worse than alcohol, drugs and gambling.

${ }^{47}$ Fiachra Gibbons, "Erdogan's Chief Adviser Knows What's behind Turkey's Protests — telekinesis," Guardian, July 13, 2013, http://www.theguardian.com/commentisfree/2014/jul/13/erdogan-turkey-proteststelekinesis-conspiracy-theories.

${ }^{48}$ Ozan Varol, “Turkey's Many Occupational Hazards," Huffington Post, May 16, 2014, http://www.huffingtonpost.com/ozan-varol/turkey-coal-mining-occupational_b_5340638.html.

${ }^{49} \mathrm{He}$ appeared again on television a short time later to retract his accusations, saying that far from hitting him, Erdogan was trying to protect him.

${ }^{50}$ See Karl Vick, “Anger at Turkish Mine Disaster Rebounds on Erdogan,” Time, May 14, 2014, http://time. com/99675/turkey-mine-disaster-erdogan-soma/. See also "U.S. Rejects 'Use of Unprovoked Violence' against Soma Protestors,” Today's Zaman, May 20, 2014, http://www.todayszaman.com/_us-rejects-use-ofuprovoked-violence-against-soma-protestors_348221.html.

51 "Der Spiegel Withdraws Reporter after Death Threats over Soma Disaster Story," Hurriyet Daily News, May 20, 2014, www.hurriyetdailynews.com/der-spiegel-withdraws-reporter-after-death-threats-over-somadisaster-story.aspx?pageID $=238 \& n I D=66746 \& N e w s C a t I D=339$.

${ }^{52}$ From the address given by Mr. Davutoglu at the Statesmen's Forum, Center for Strategic and International Studies, Washington, DC, February 10, 2012, www.csis.org/event-turkeys-foreign-policy-objectives-changing-world.

53 "Syria Rejects Imposed Reforms, Muslim Brotherhood Not to Form a Party: Syrian FM to Turkish Newspaper," Al Arabiya, February 28, 2012. The brotherhood fomented a series of uprisings that culminated in the bloody confrontation with the military at Hama in 1982, www.english.arabiya.net/articles/2012/02/28/197511.html. 
54 "PM Erdogan Warns Assad, 'You Reap What You Sow," Sabah, February 8, 2012, www.english.sabah.com. tr/2012/02/08/pm-erdogan-warns-assad-you-reap-what-you-sow. See "Erdogan Tells Assad to Draw Lessons from Fate of Gaddafi, Hitler," Today's Zaman, November 22,2011, www.todayzaman.com/news-263554/ erdogan-tells-assad-to-draw-lessons-from-fate-of-gaddafi-hitler.html. Also Soli Ozel, "Turkish Foreign Policy Losing Ground in Syria; Davutoglu Calls Assad a 'Milosevic,'” Al-Monitor, January 31, 2012. Originally published in Haberturk under the title "Before Losing the Ball Bearings," www.al-monitor.com/pulse/politics/2012/01/before-losing-the-ball-bearings.html.

${ }^{55}$ Sharmine Narwani, "Please Ambassador Ford. Name Me a 'Moderate' Syrian Rebel," Mideast Shuffle, June 4, 2014, www.mideastshuffle.com/2014/06/04/please-ambassador-ford-name-me-a-moderate-syrian-rebel/.

${ }^{56}$ Tulin Daloglu, “Biden’s Apology Hides the Truth,” Al-Monitor, October 6, 2014, www.al-monitor.com/ pulse/originals/2014/10/turkey-united-states-biden-erdogan-middle-east-harvard.html.

${ }^{57}$ Fehim Tastekin, "Fall of Kassab Will Be Costly for Turkey," Al-Monitor, March 31, 2014, www.al-monitor. com/pulse/tr/security/2014/03/fall-kassab-syria-costly-turkey.html.

${ }^{58}$ C. J. Chivers and Eric Schmitt, "Saudis Step Up Help for Rebels with Croatian Arms," New York Times, February 25, 2013, http:/nytimes.com/2013/02/26/world/middleeast/in-shift-saudis-are-said-to-arm-rebelsin-syria.html?pagewanted=all. See also C.J. Chivers and Eric Schmitt, "Arms Airlift to Syria Rebels Expands With Aid from CIA," New York Times, March 24, 2013, http://www.nytimes.com/2013/03/25/world/middleeast/arms-airlift-to-syria-rebels-expands-with-cia-aid.html?pagewanted-r=0.

${ }^{59}$ In late April 2012, Lebanese authorities intercepted and impounded a container ship, the Lutfullah II, registered in Sierra Leone and carrying weapons from Libya to the northern Lebanese port city of Tripoli. According to reports in Beirut, eyewitnesses saw the ship being loaded in Benghazi where "it is well known at the docks that Qatar and Saudi Arabia control a total of five warehouses in the area of Benghazi and Misurata and supplied the weapons and money to hire the Lutfullah II container vessel." Franklin Lamb, "The Lutfullah II Arms-Smuggling Scandal," Tripoli, Lebanon, Counterpunch, May 4-6, 2012, www.counterpunch. org/2012/05/04/the-lutfullah-II-arms-smuggling-scandal.

${ }^{60}$ In January, 2014, on the orders of a prosecutor, jandarma began searching a truck heading for the Syrian border in Hatay province. They reportedly had already found arms and ammunition as well as some "humanitarian" aid when the search was called off by the local governor, Celalettin Lekesiz ("without a stain"). Disclosing in an official report that the three men in the truck were MIT personnel, he said that as they were responsible only to the prime minister's office, under a law passed in 2012, the prosecutor had "exceeded his authority" by ordering it searched. The jandarma who searched the truck were later prosecuted. There have been other examples of conflicts between police and higher authorities over trucks carrying arms to Syria. See Fevzi Kizilkoyun, "Turkish Governor Blocks Police Search on Syria-Bound Truck Reportedly Carrying Weapons," Hurriyet Daily News, January 2, 2014, http://hurriyetdailynews.com/turkish-governor-blockspolkice-search-on-truck-reportedly-carrying-weapons-.aspx?PageID=238\&NID=60494\&NewsCatID=341. See also Serpil Cevikcvan, "Is Turkey Sending Weapons to Syria under Guise of Aid?" Al-Monitor, January 5, 2014, http:/www.al-monitor.com/pulse/security/2014/01/turkey-truck-stopped-weapons-syria-controversy. html.

${ }^{61}$ Sharmine Narwani, "Coalition of the Clueless," Russia Today, September 25, 2014, www.rt.com/opedge/190684-syrian-coalition-air-strikes-isis/.

${ }^{62}$ For example, see Jesse Colombo, "Why the Worst Is Still Ahead for Turkey's Bubble Economy," Forbes, March 5, 2014, www.forbes.com/sites/jessecolombo/2014/03/05/why-the-worst-is-still-ahead-for-turkeysbubble-economy/.

${ }^{63}$ Extending into the arts. The latest example is a ban on the performance of music written by the pianist/ composer Fazil Say. See "Ministry Removes Fazil Say from Presidential Symphony's New Season," Today's Zaman, October 20, 2014. In 2013, Say was sentenced to a 10-month suspended jail sentence by a Turkish judge for sending Twitter messages regarded as insulting to Islam, www.todayszaman.com/newsDetail. action;jsessionid-WQW1pdb9uBxjuQgFt60jfM9E?newsid=362110\&columnistid=0. 